\title{
Acute generalized exanthematous pustulosis induced by hydroxychloroquine associated with human leukocyte antigen-B51 (HLA-B51), DR1 101,04, DQ03,05, and for the first time in the literature with HLA-B15
}

Hidroksiklorokin ile indüklenen ve insan lökosit antijeni-B5 1 (HLA-B5 1), HLADR1 101,04, HLA-DQ03,05 yanında literatüde ilk kez HLA-B15 ile ilișkili akut generalize ekzantematik püstüloz

( Eleni Klimi

Thriassio General Hospital, Clinic of Dermatology, Athens, Greece

Keywords: Pustulosis, hydroxychloroquine, HLA

Anahtar Kelimeler: Püstüloz, hidroksiklorokin, HLA

\section{To the Editor,}

Acute generalized exanthematous pustulosis is a rare drug eruption that affects $1-5$ in a million individuals mainly females characterized by a sudden occurrence of pinhead sized non follicular sterile pustules on erythematous areas, accompanied by fever and pruritus' ${ }^{1}$. Visceral organ involvement may also occur. Medicines that induce acute generalized exanthematous pustulosis (AGEP) include antibiotics- ampicillin, macrolides, quinolones, sulfonamideschloroquine, hydroxychloroquine, terbinafine and diltiazem². It is currently uncertain whether AGEP is strictly human leukocyte antigen (HLA) restricted. In 1995 Bernard et al. ${ }^{3}$ showed a statistically significant augmentation of frequency of the alleles HLA-B51, DR11 and DQ3 associated with acute generalized exanthematous pustulosis although an association with a specific drug has not been reported ${ }^{3}$. We present a case of acute generalized exanthematous pustulosis AGEP - induced by hydroxychloroquine associated with HLA-B51, DR110,1, O,4, DQ03,05 and for the first time in the literature with HLA-B15.

A 72-year old woman of Caucasian origin was admitted for fever, pruritus and rash of one day duration. She was treated for hypothyroidism with thyroxine $75 \mu \mathrm{gr}$ daily. For the last two weeks she had been taking hydroxychloroquine $200 \mathrm{mgr}$ twice daily for joint pains although a definite diagnosis had not been made. Clinical examination revealed good general condition, fever $38.2 \mathrm{C}$ and an eruption of erythematous patches on the back, - between the mammary glands- and lower limbs covered with non-follicular pustules forming at certain areas lakes of pus. Mucous membranes were intact. Figure 1. Full blood count showed leucocytosis with neutrophilia, liver tests were normal. Histology showed a subcorneal pustule with neutrophils, perivascular neutrophilic infiltrate in the dermis, compatible with acute generalized exanthematous pustulosis - AGEP Figure 2. The eruption regressed following withdrawal of hydroxychloroquine and

Yazışma Adresi/Address for Correspondence: Eleni Klimi MD, Thriassio General Hospital, Clinic of Dermatology, Athens, Greece Tel.: +302132028005 E-posta: elenik2019@yahoo.com Geliş Tarihi/Received: 07.11.2019 Kabul Tarihi/Accepted: 20.01.2020 ORCID: orcid.org/0000-0001-5113-5640

(C) Copyright 2020 by Turkish Society of Dermatology and Venereology

Turkderm - Turkish Archives of Dermatology and Venereology published by Galenos Yayınevi. 


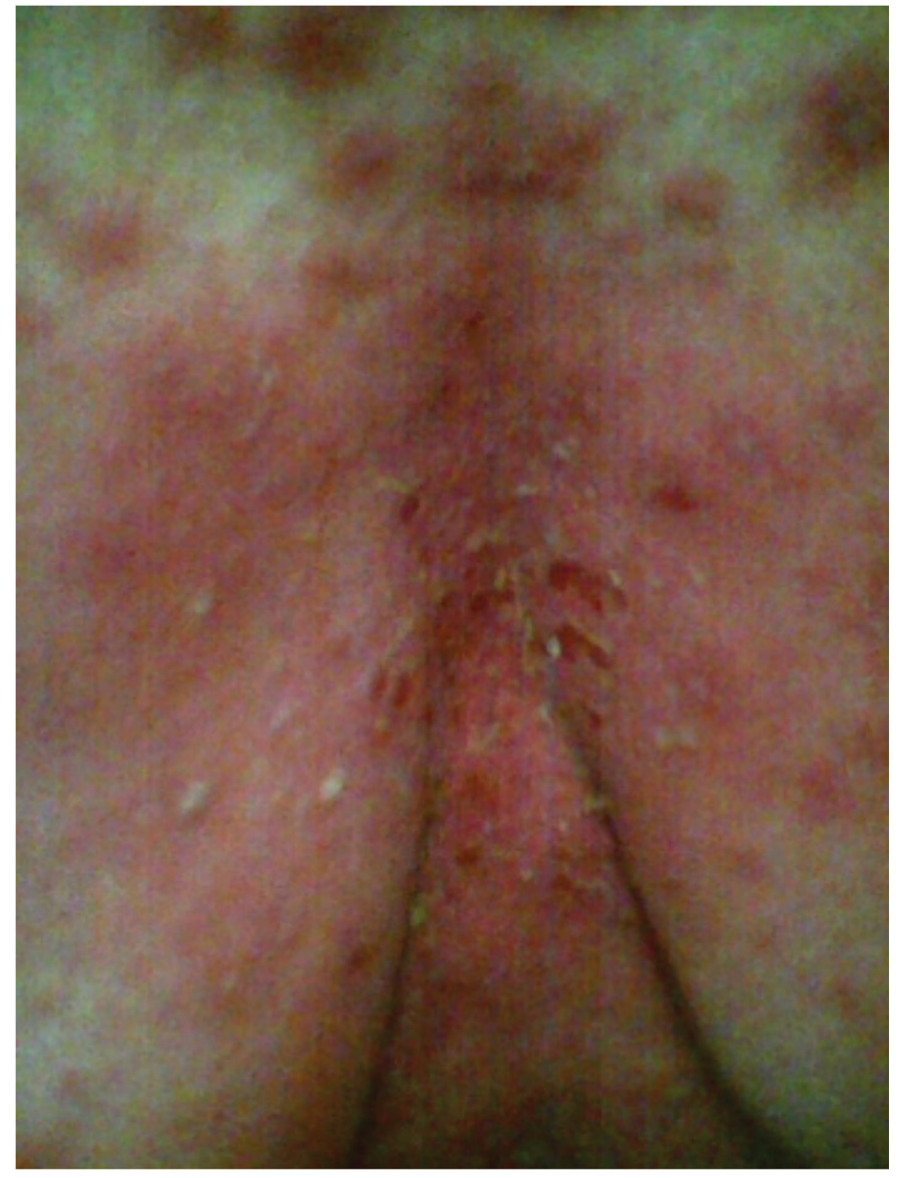

Figure 1. Erythema and pustules between both mammary glands

administration of oral steroids 3 weeks later. Thorax Radiography and abdomen tomography were normal. Serum titers for cytomegalovirus, Epstein-Barr virus, Parvovirus B19, Coxcackie, Echo Herpes 6 and 7 viruses, anti-nuclear antibody and rheumatoid factor were negative. The HLA typing was performed for the HLA-A, B and C antigens using the sequence specific oligonucleotide-polymerase chain reaction (PCR) and for the HLA-DR, DQ the sequence specific primer PCR based assay. The patient proved to be positive for the alleles HLA-B51, HLA-B15, HLA-DR1101,04 and HLA-DQ03,05.

HLA genetic testing for B1502 is recommended prior to initiation of carbamazepine therapy because this anti-epileptic may induce Stevens Johnson and or toxic epidermal necrolysis. HLA-B allele is the most common determinant of the most severe types of drug hypersensitivity reactions, including SJS, TEN, HSS and rashes ${ }^{4}$. AGEP is a very rare drug induced condition with very few cases HLA investigated. Although not associated with severe mortality (4\%), AGEP may provoke considerable morbidity, the reported patient has been hospitalized for a month. Furthermore the HLA-B15 positivity reported is an interesting finding

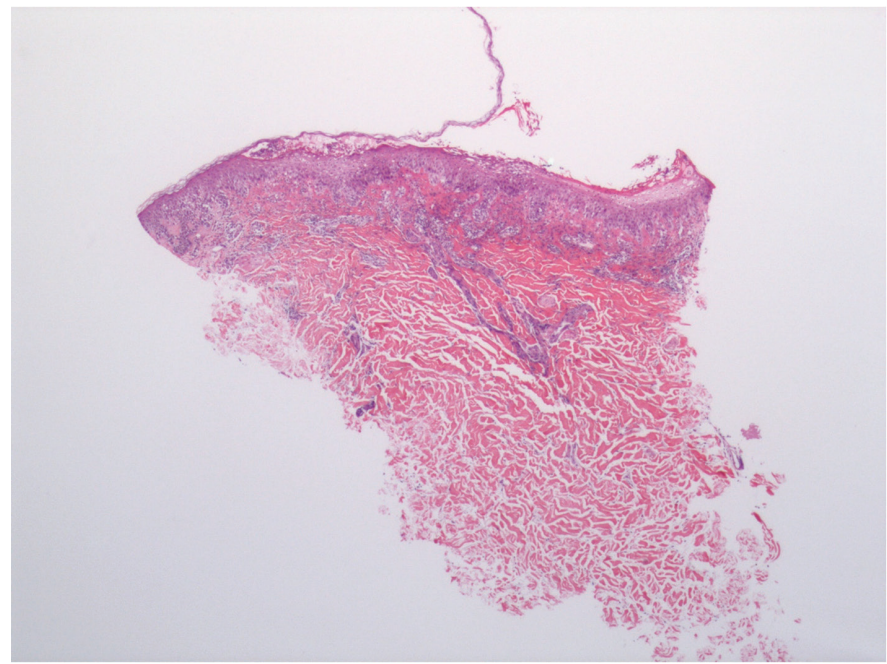

Figure 2. Intraepidermal pustule and perivascular infiltrates consisting of neutrophils in the dermis (hematoxylin and eosin, $x 10$ )

because HLA-B15 is rare in Caucasians-carrier frequency $<1 \%$. After review of the literature the reported case seems to be the first case of confirmed AGEP in a Caucasian associated with HLA-B51, HLA DR1101,04, HLA-DQ03,05 and with HLA-B15, an HLA-B allele, which although rare in Caucasians, is related-such as HLA-B5701, HLA-B5801 (carbamazepine induced AGEP) 5 to cutaneous adverse drug reactions in Asian populations. Informed consent was obtained.

\section{Ethics}

Informed Consent: It was obtained.

Peer-review: Externally peer-reviewed.

Financial Disclosure: The authors declared that this study received no financial support.

\section{References}

1. Paulman M, Mackenhaupt M: Severe drug hypersensitivity reactions: clinical pattern, diagnosis, etiology and therapeutic options. Curr Pharm Des 2016;22:6852-61

2. Pavlos R, Mallal S, Ostrov D, Pompeu Y, Phillips E: Fever, rash and systemic symptoms: understanding the role of virus and HLA in cutaneous drug allergy. J Allergy Clin Immunol Pract 2014;2:21-33.

3. Bernard $P$, Lizeaux-Parneix $V$, Miossec $V$ : HLA et prédisposition génétique dans les pustuloses exanthématiques aiguës généralisées (PEAG) et dans les exanthèmes maculo-papuleux (EMP). Ann Dermatol Venereol 1995;122:389.

4. Wei CY, Ko TM, Shen CY, Chen YT: A recent update of pharmacogenomics in drug-induced-severe skin reactions. Drug Metab Pharmacokinet 2012;27:132-41.

5. Manoharan A, Kumar AS, Sreedevi $A$, Sathishkannan AD, Gaddam BK HLA-B 5701 and HLA-B 5801 in an Indian Patient with anti-epileptics induced cutaneous adverse drug reactions. Eur J Clin Pharmacol 2019;75:599-601. 